Article

\title{
Determinants of Farmers' Decisions on Risk Coping Strategies in Rural West Java
}

\author{
Dadang Jainal Mutaqin 1,2 \\ 1 Graduate School of International Development (GSID), Nagoya University, Nagoya 464-8601, Japan; \\ mutaqin.dadang.jainal@b.mbox.nagoya-u.ac.jp \\ 2 National Development Planning Agency (Bappenas), the Republic of Indonesia, \\ Directorate of Forestry and Water Resource Conservation, Jakarta 10310, Indonesia
}

Received: 7 December 2018; Accepted: 2 January 2019; Published: 5 January 2019

\begin{abstract}
The impact of natural hazards on agriculture in Indonesia is becoming increasingly severe. Therefore, improving farmers' capacity to undertake risk coping strategies is essential to maintaining their prosperity. The objective of this study was to investigate the determinants of farmers' decisions on ex ante and ex post coping strategies in rural West Java, Indonesia. The study was based on a field survey of 180 farmers conducted in the Garut district from July to October 2017. The study used the protection motivation theory framework and applied three econometric models: binomial logit model, zero truncated Poisson regression model, and multinomial logit model. Most farmers (74.4\%) adopted ex ante coping strategies. They were characterized as having higher risk aversion per capita expenditure and disaster experience, but lower discount rates and percentage of damage and locations in downstream and midstream areas. Coping appraisal perceptions were found to be important factors in the risk coping analysis. Four determinants of the decision on the number of ex ante coping strategies adopted were: per capita expenditure, land size, disaster experience, and access to financial institutions. The most common ex post coping strategy adopted by farmers was the middle-stress type.
\end{abstract}

Keywords: ex ante and ex post coping strategies; farmer decisions; protection motivation theory; rural West Java

\section{Introduction}

Farmers adopt strategies to cope with farming risks to sustain their livelihood. These strategies can be grouped into two categories. The first is the ex ante strategy, called the protective response, which helps to smooth income flow to households. The second is the ex post strategy, which helps to smooth consumption by households [1-4]. Under a given condition, farmers select ex ante or ex post strategies to cope with farming risks.

Farmers tend to adopt ex post strategies to minimize the impacts of disasters [3]. Ex post strategies are viewed as immediate responses to problems [5]. According to the World Bank [6], in principle, the best approach to reduce risks is to take actions that anticipate the adverse impacts of disasters, or adopt ex ante strategies, because the function of ex post strategies is to address the failures of ex ante strategies.

The impact of natural hazards on agriculture in Indonesia, which appear to be due to climate change, has become increasingly severe. From 2005 to 2015, for example, the number of natural hazards, such as flooding and droughts, doubled [7]. As weather warms and humidity increases, pests and diseases occur more often and destroy plants. The Ministry of Agriculture (MoA) [8] reported an increase in attacks to paddy crops by pests, such as brown plant hoppers, by as much as $180 \%$ in 2014 compared to 2012. To minimize the calamitous impact of disasters at the farm household 
level, it is important to enhance farmers' capacity for prevention and mitigation [9]. In such capacity building, institutional support by the government is indispensable.

One government policy that enhances farmers' risk coping is agricultural insurance, which the Indonesian government decided to implement in 2016. Currently, the insurance premium is highly subsidized ( $80 \%$ of the premium is subsidized). However, its participation rate in 2016 was still low, at around $20 \%$ of the target farmers [10]. For the Indonesian government to motivate farmers to purchase agricultural insurance as a risk-coping strategy, as a first step toward the amendment of agricultural insurance policies, it is important to understand farmers' risk-coping behaviors and their constraints, especially for farmers who have not yet purchased agricultural insurance.

Many approaches can be used to investigate individuals' decisions on risk coping strategies. Barnett et al. [11] applied an adaptation pathway approach to investigate coping strategies adopted to minimize the adverse impacts of sea level rise in southeastern Australia. Osbahr et al. [12] examined farmers' strategies in adapting to climate change and variability in South Africa by applying the livelihood adaptation framework. Huitema et al. [13] clarified the importance of interventions and governance at higher jurisdictional levels conducted by government agencies for adaptation to climate change. Their study contributed to the development of the governance of adaptation approach. Pelling [14] identified the contribution of social capital theory to enhancing the understanding of individuals and social collectives in responding to climate change.

Grothmann and Patt [15] argued that psychological aspects have to be considered in the adaptation process. Therefore, they proposed a socio-cognitive model of adaptation and adaptive capacity to explain the process of individuals' adaptation to climate change by addressing psychological factors. The model is based on protection motivation theory (PMT) developed by Rogers [16]. Even though the theory is used in psychological research on health behavior, it has also been successfully applied in other research fields, including risk management [17]. Results of studies of natural hazards (e.g., flooding, earthquake, and wildfire preparedness) such as by Grothmann and Reusswig [17], Bubeck et al. [18], Martinn et al. [19], and Mankad et al. [20] highlight the potential for PMT-based models in predicting farmer behavior with respect to risk coping strategies. The application of the socio-cognitive model of adaptation and adaptive capacity to explain farmers' risk coping behavior in developing countries is still limited, particularly in Southeast Asia, including Indonesia.

The present study had two objectives: (1) to identify determinants of decisions on ex ante coping strategies; and (2) to identify determinants of decisions on ex post coping strategies. For the conducted analysis, the choice to adopt, number of strategies, and types of strategies are considered as aspects of decisions. In reality, not all farmers adopt ex ante coping strategies, whereas almost all farmers who have experience with disasters adopt ex post coping strategies. When adopting ex post coping strategies after a certain disaster has occurred, the stress level of ex post coping strategy influences farmers' capacities for choosing ex ante coping strategies in the future (adaptive capacity). Hence, the above-mentioned aspects are significant to ex post strategy analysis. The present study incorporates socio-psychological aspects of adaptation as variables in the estimation. It is therefore an essential study of the socio-cognitive model of adaptation and adaptive capacity $[15,17,21]$.

\section{Methodology}

\subsection{Framework}

Many definitions of coping strategies and adaptive capacity have been introduced. For instance, coping strategies have been defined as the ability of individuals to respond to hazard occurrences and to protect themselves from a hazard's potential impacts within existing structural constraints [22,23]. Adaptive capacity is defined as the ability to transform an organization or structure to survive under the existence of harm. Yohe and Tol [24] defined coping strategies as a range of actions that are available to respond to the risk perception of climate change in a certain policy context, whereas they defined adaptive capacity as the ability to transform the available inputs that determine the level of 
capacity to cope with the risks. For the present study, a coping strategy was defined as an adaptation to and anticipation of expected future risks and as an immediate response to minimize the impacts of shocks [25]. Adaptive capacity is the ability of individuals to prepare in advance for stresses and to adapt and adjust to the effect of the stresses $[25,26]$.

PMT explains decisions to take protective responses based on socio-psychological factors. According to the PMT presented in Figure 1, two processes are involved in risk evaluation. The first is a threat appraisal known as risk perception, which involves two assessments: risk impact perception and risk probability perception. The second is a coping appraisal, which involves three evaluations: coping efficacy, self-efficacy, and cost efficacy [27]. Based on PMT, the key mediator of the relationship among threat appraisal, coping appraisal, and behavior is protection motivation [27-29], which is a combination of threat and coping appraisal assessments. The processes of the two assessments are sequential [30]. Before conducting coping appraisal (assessment of adaptive options), farmers must first believe that a threat is present $[27,30]$. Threat appraisal evaluates the perceived probability and impact of harm. This process occurs before coping appraisal because to evaluate the adaptive options farmers have to perceive a threat [17]. The combination of threat and coping appraisal assessments determines the protection motivation. If the protection motivation is high, this motivation should be converted into taking ex ante coping strategies; otherwise, it will result in taking ex post coping strategies. Taking ex post coping strategies, furthermore, influences the adaptive capacity of farmers to anticipate expected future risks, which depends on the resource value and its degree of reversibility allocated for taking ex post coping strategies.

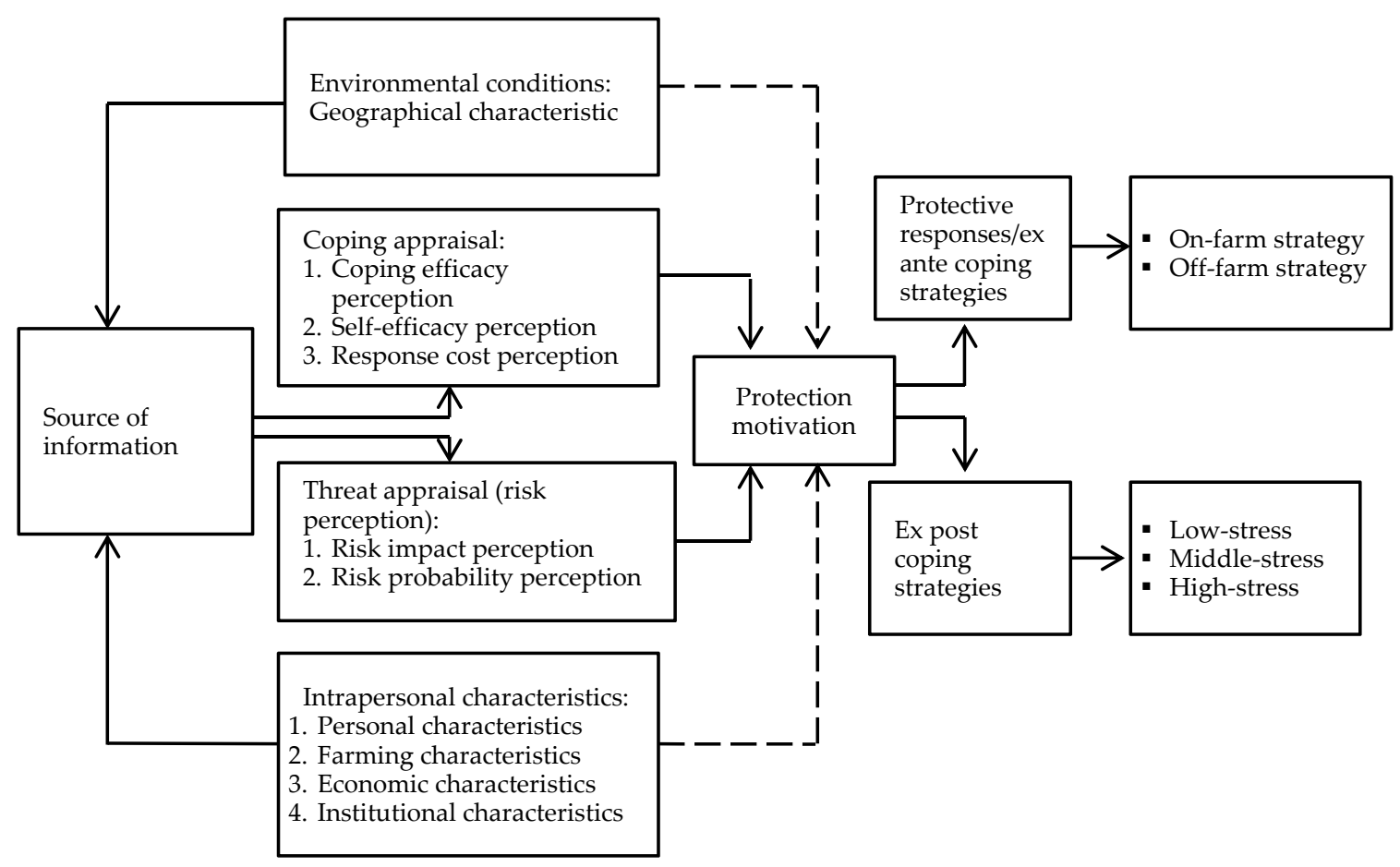

Figure 1. Framework used in the study. Modified from Rogers and Prentice-Dunn [27] (Figure 1, p. 114). Note: $\rightarrow=$ the process of PMT; $-\rightarrow=$ predicted to directly influence protection motivation.

In this study, ex ante coping strategies were grouped into on-farm and off-farm strategies. Ex post coping strategies were grouped into three types of stress level: low, middle, and high [31,32]. The stress level depends on the allocated resource value and its degree of reversibility. Table 1 shows types of ex post coping strategies based on stress level. 
Table 1. Types of ex post coping strategy based on stress level.

\begin{tabular}{|c|c|c|c|}
\hline Stress Type & Characteristic & Strategy & Impact \\
\hline Low & $\begin{array}{l}\text { Resources allocated are low and } \\
\text { reversible }\end{array}$ & $\begin{array}{l}\text { - } \quad \text { Change consumption pattern } \\
\text { - Increase household budget }\end{array}$ & $\begin{array}{ll}\text { - } & \text { Change lifestyle } \\
\text { - } & \text { Households asset reallocation }\end{array}$ \\
\hline Middle & $\begin{array}{l}\text { - Resources allocated are high } \\
\text { and less reversible } \\
\text { - } \quad \text { Reduces adaptive capacities in } \\
\text { the future }\end{array}$ & $\begin{array}{l}\text { - } \quad \text { Utilize savings } \\
\text { - } \quad \text { Borrow from formal and } \\
\text { - } \quad \text { Get help from relatives } \\
\text { - } \quad \text { Migrate to find a job }\end{array}$ & $\begin{array}{ll}\text { - } & \text { Reduce financial assets } \\
\text { - } & \text { Debt } \\
& \text { Increase social obligation }\end{array}$ \\
\hline High & $\begin{array}{l}\text { - } \quad \text { Resources allocated are difficult } \\
\text { to reverse } \\
\text { - } \quad \text { Increases vulnerability to } \\
\text { future shocks }\end{array}$ & $\begin{array}{ll}\text { - } & \text { Sell consumption assets } \\
\text { - } & \text { Sell productive assets } \\
\text { - } & \text { Take children out of school }\end{array}$ & $\begin{array}{l}\text { - } \quad \text { Reduce household productivity } \\
\text { - } \quad \text { Reduce accessibility to } \\
\text { - } \\
\text { financial markets } \\
\text { Social isolation }\end{array}$ \\
\hline
\end{tabular}

The present study adopted PMT as a framework in combination with socio-psychological and socio-economic factors. The socio-economic factors that are predicted to influence the types of ex ante coping strategies include personal, economic, farming, financial (institutional access), and geographical factors [29,33-39]. In the original PMT, protection motivation merely depends on psychological factors (coping appraisal and threat appraisal), in which intrapersonal and environmental characteristics act as sources of information $[16,27]$. In the present study, as shown in Figure 1, personal, farming, economic, institutional, and geographical characteristics were predicted to act not only as sources of information but also as direct influences on protection motivation.

\subsection{Study Site}

The Garut district, in the West Java Province, Indonesia, was chosen as a study area. This district has been one of the most vulnerable areas to natural hazards since 2012 [7]. The natural hazards that commonly occur include flooding, excessive rainfall, and pests and diseases [7,8]. For example, a flood at the end of 2016 was the worst flood in the district [7] and most people in the district rely on agriculture for their livelihood [40]. The district has approximately 122,082 ha of farmland, which accounts for around $10 \%$ of the total paddy area in the province [41]. Garut's poverty rate was around $12.47 \%$ in 2014 [40]. In 2016, the number of farmers purchasing agricultural insurance was the lowest among all districts in the province [10].

\subsection{Data Collection}

The field survey was conducted from August to October 2017 in the north of Garut, among one of the district's areas most vulnerable to disasters [7]. There are 21 sub-districts in the area distributed upstream, midstream, and downstream of the Cimanuk River. The respondents selected were paddy growers who had not yet purchased agricultural insurance. The number of respondents $(N)$ was calculated as follows:

$$
N=\frac{Z^{2}(P) \times(1-P)}{C I^{2}}=\frac{1.96^{2} \times 0.5 \times(1-0.5)}{0.075^{2}}
$$

where $\mathrm{Z}$ is the confidence level, $\mathrm{CI}$ is the level of margin error, and $P$ is the degree of variability. By using a $50 \%$ degree of variability, $95 \%$ confidence level $(Z=1.96)$, and $7.5 \%$ margin error, the total number of respondents targeted was around 180 farmers.

Respondents were selected using multistage cluster sampling. First, two sub-districts were randomly selected from each group of sub-districts: upstream, midstream, and downstream. The sub-districts chosen were Samarang and Bayongbong in the upstream area, Tarogong Kidul and Tarogong Kaler in the midstream area, and Banyuresmi and Leuwigoong in the downstream 
area (Figure 2). Second, from each sub-district, two villages were randomly chosen. Third, from each village, 30 farmers were randomly selected. Therefore, there were 180 farmers as respondents.

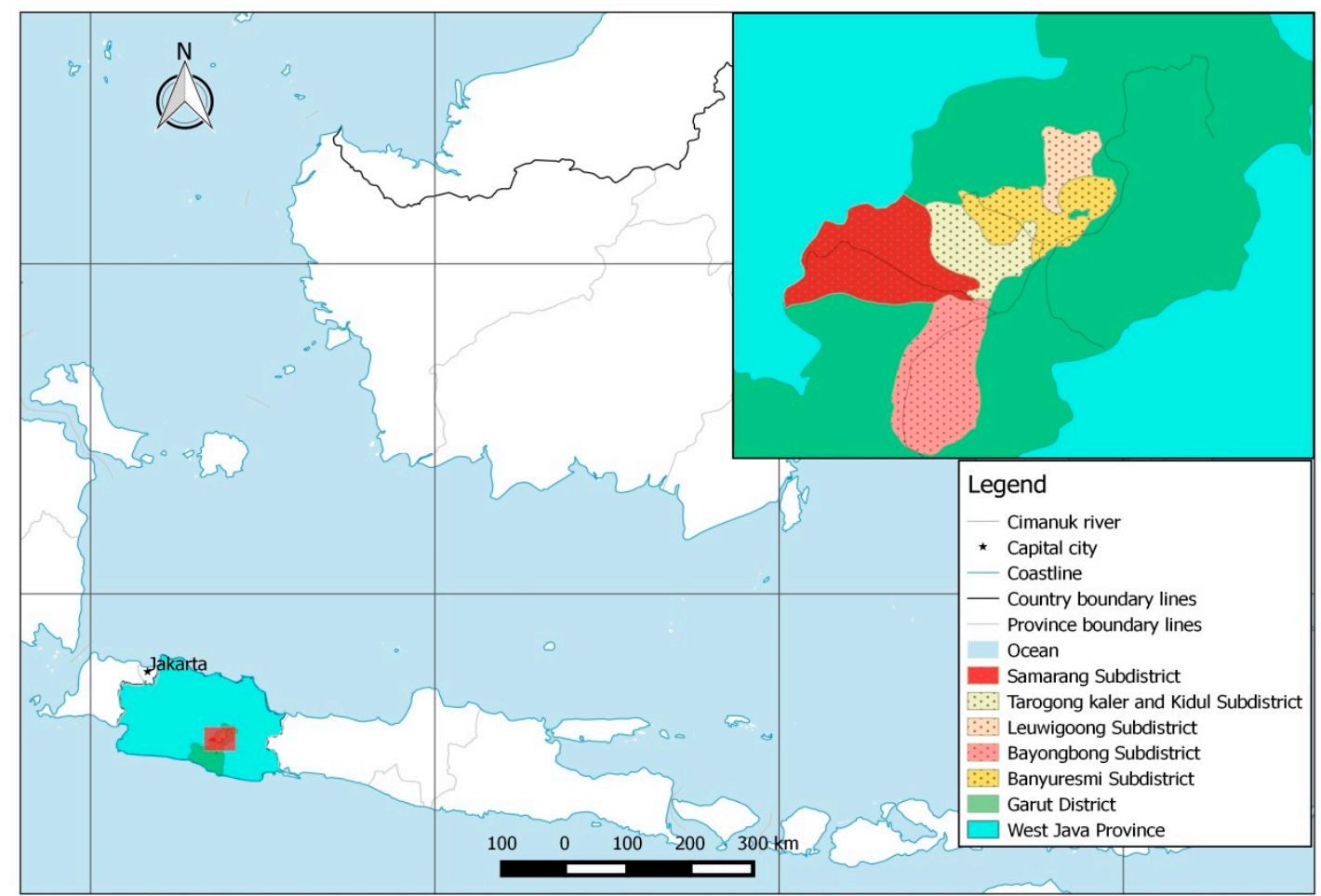

Figure 2. Location of the study district and the study's six sub-districts.

Face-to-face interviews were conducted to collect data on farmers' ex ante and ex post coping strategies. First, farmers were asked whether they knew of agricultural insurance. If they did not, the interview was continued; if so, they were excluded. The farmers were asked whether they had performed ex ante coping strategies in the last five years (January 2012-December 2016) to reduce the impact of disasters. If they had, they were asked what types of coping strategies they had adopted. As for ex post coping strategies, farmers were asked what types of ex post coping strategies they had adopted after disasters had occurred. Farmer characteristics (personal, economic, financial, institutional, and farming) were collected. At the end of the interview, to measure risk behavior, trust, and discount rate, a game was played following procedures used by Schechter [42] and Kirby et al. [43] in which risk behavior and trust were identified by applying a risk and trust game (economic experiment). The discount rate was identified by examining farmers' choices between delayed and immediate rewards. The key indicators/questions included in the interviews were as follows:

- Adopting an ex ante coping strategy: take/do not take an ex ante coping strategy (dummy)

- Number of ex ante coping strategies taken (number of strategies)

- Type of ex post coping strategies taken: type of ex post coping strategy taken based on stress level (dummy)

- Age of farmer (years)

- Education level of farmer: school years (number of years)

- Sex of farmer (dummy)

- Risk behavior of farmer: absolute value of money in the risk game

- Discount rate of farmer: absolute value of farmer's preference in the discount rate game

- Trust value of farmer: absolute value of money given by a farmer in a trust game

- Disaster experience: number of disasters experienced per season 
- Percentage of damage: the highest percentage of damage

- $\quad$ Risk impact perception (Likert scale: very low, low, high, very high) (categorical data)

- $\quad$ Risk probability perception (Likert scale: very low, low, high, very high) (categorical data)

- Coping efficacy appraisal (Likert scale: very low, low, high, very high) (categorical data)

- Self-efficacy appraisal (Likert scale: very low, low, high, very high) (categorical data)

- Cost appraisal (Likert scale: very low, low, high, very high) (categorical data)

- Per capita expenditure: absolute value of per capita expenditure of food and non-food

- Asset value: absolute value of total physical (non-land) and financial asset

- Land size: absolute value of land size managed by a farmer

- Type of land (irrigated or rain-fed) (dummy)

- Bank account ownership (dummy)

- Type of landholding (sharecropping, rent-in cash, privately owned land) (dummy, privately owned land as the base case)

- Location of farmer (downstream, midstream, and upstream) (dummy, upstream as the base case)

\subsection{Data Analysis}

\subsubsection{Binary Data Estimation: Take or Not Take}

The decision on adopting ex ante coping strategies was recorded as yes or no, categorized as a binary response. The model for analysis is the binomial logit model.

$$
y\left\{\begin{array}{l}
1=\text { if farmer takes an ex ante coping strategy } \\
0=\text { if farmer does not take an ex ante coping strategy }
\end{array}\right.
$$

The decision is influenced by the expected utility of wealth from adopting coping strategies. If the utility level after disasters without ex ante coping strategies is $U\left(\omega^{a}\right)$ and the utility level after disasters with ex ante coping strategies is $U\left(\omega^{b}\right)$, farmers adopt ex ante coping strategies when they believe that coping strategies will stabilize the utility level compared to without coping strategies. This occurs when $U\left(\omega^{b}\right)>U\left(\omega^{a}\right)$. When farmers decide to adopt ex ante coping strategies, the value is called a latent variable, being unobservable. The latent variable $\left(U^{*}\left(\omega_{i}\right)\right)$ can be determined by factors that are predicted to influence the decision. Therefore, the utility level of wealth can be written as:

$$
U^{*}\left(\omega_{i}\right)=\sum_{k=1}^{K} \beta_{k} x_{k i}+\varepsilon_{i} i=1,2,3, \ldots, n
$$

where $x_{i}$ represents determinants of a decision such as personal characteristics, and $\beta$ and $\varepsilon$ are the coefficient and error term, respectively. The decision to adopt ex ante coping strategies can be rewritten as follows:

$$
y_{i}^{*}\left\{\begin{array}{l}
1 \text { if } U^{*}\left(\omega^{\mathrm{b}}\right)>U^{*}\left(\omega^{\mathrm{a}}\right) \\
0 \text { if } U^{*}\left(\omega^{\mathrm{b}}\right)<U^{*}\left(\omega^{\mathrm{a}}\right)
\end{array}\right.
$$

According to Wooldridge [44], supposing that the probability of farmer $i$ adopting ex ante coping strategies is represented by $P_{i}$ and $E$ is the expected value, the equation for the logit model can be written as:

$$
E\left(y=1 \mid x_{i}\right)=l_{n}\left(\frac{P_{i}}{1-P_{i}}\right)=\ln e^{\mathbf{x}_{i}^{\prime} \beta}=\mathbf{x}_{i}^{\prime} \beta
$$

where $e$ is the base of the natural logarithm and $\mathbf{x}_{i}^{\prime} \beta$ is the function of farmers' characteristics. The equation of logit model can be rewritten as: 


$$
\begin{gathered}
\ln \left(\frac{P_{i}}{1-P_{i}}\right)=\beta_{0}+\beta_{1} \text { AGE }+\beta_{2} \text { EDU }+ \\
\beta_{3} \text { SEX }+\beta_{4} \text { RISK }+\beta_{5} \text { DISC }+\beta_{6} \text { TRUST }+\beta_{7} \text { DISEXP }+\beta_{8} \text { PDM }+\beta_{9} \text { RIP }+\beta_{10} \text { RPP }+ \\
\beta_{11} \text { CEA }+\beta_{12} \text { SEA }+\beta_{13} \text { CA }+\beta_{14} \text { EXPD }+\beta_{15} \text { ASST }+\beta_{16} \text { LAND }+\beta_{17} \text { TF }+\beta_{18} \text { SHARE }+ \\
\beta_{19} \text { RIC }+\beta_{20} \text { BANK }+\beta_{21} \text { DSTR }+\beta_{22} \text { USTR }+\varepsilon_{i}
\end{gathered}
$$

One important statistical feature in the logit model is the marginal effect that shows the change of probability on adopting ex-ante coping strategies when there is a unit change in an independent variable, and the other independent variables are constant. The marginal effect $\left(\frac{\partial y_{i}}{\partial x_{k}}\right)$ of independent variable $k$ with coefficient $\beta_{k}$ can be written as follows:

$$
\frac{\partial y_{i}}{\partial x_{k}}=\frac{e^{\mathbf{x}_{i}^{\prime} \beta}}{\left(1+e^{\mathbf{x}_{i}^{\prime} \beta}\right)^{2}} \beta_{k}
$$

The proportion between the probability of adopting and not adopting ex-ante coping strategies is called the odds ratio. The equation is as follows:

$$
\frac{P_{i}}{1-P_{i}}=e^{\mathbf{x}_{i}^{\prime} \beta}
$$

\subsubsection{Count Data Estimation: Number of Ex Ante Coping Strategies Adopted}

There is a possibility that there are different behaviors among farmers who adopt ex ante coping strategies. Due to different determinants, some farmers adopt one strategy, whereas others adopt more than one. When analyzing the number of ex ante coping strategies adopted by farmers, the data are count data. One appropriate model to analyze count data with positive responses $(y>0)$ is the zero truncated Poisson regression model (ZTPRM).

The econometric equation in the ZTPRM is based on Green [45]. Suppose that the number of ex ante coping strategies chosen by a farmer in a given period is $y$. To identify the effects of independent variables $(x)$ on $y$, the Poisson distribution of independent variables $(x)$ is analyzed. The Poisson distribution is specified by the mean value. If $e$ is the base of the natural logarithm, the expected value $(E)$ of mean parameter $(\gamma)$ is an exponential function, as follows:

$$
E\left(y_{i} \mid \mathbf{x}_{i}\right)=\gamma_{i}=e^{\mathbf{x}_{i}^{\prime} \beta}
$$

When $y$ is a Poisson random variable conditional on $x$, the probability of the density function can be written as:

$$
P\left(y_{i}=j \mid \mathbf{x}_{i}\right)=\frac{e^{-\gamma_{i}} \gamma_{i}^{j}}{j !}, j=0,1,2,3 \ldots, n
$$

In the ZTPRM, positive values $(y>0)$ are used. Therefore, Equation (8) can be expressed as follows:

$$
\begin{gathered}
\text { if } P\left(y_{i}=0 \mid \mathbf{x}_{i}\right)=e^{-\theta} \\
P\left(y_{i}=j \mid \mathbf{x}_{i}\right)=\frac{\left(1-e^{-\theta}\right) e^{-\gamma_{i} \gamma_{i}}{ }^{j}}{j !\left(1-e^{-\gamma_{i}}\right)}, j=1,2,3, \ldots n
\end{gathered}
$$

where $j$ is the number of ex ante coping strategies adopted, which is dependent on the value of $\gamma_{i}$. Its value is influenced by farmers' characteristics $\left(\mathbf{x}_{i}^{\prime} \beta\right)$ (see Equation (7)). Supposing that EXP represents exponential function, the equation of $\gamma_{i}$ is as follows: 


$$
\begin{aligned}
E\left(y_{i} \mid \mathbf{x}_{i}\right)=\gamma_{i}= & \text { EXP }\left(\beta_{0}+\beta_{1} \text { AGE }+\beta_{2} \text { EDU }+\beta_{3} \text { SEX }+\beta_{4} \text { RISK }+\beta_{5} \text { DISC }+\beta_{6}\right. \text { TRUST } \\
& +\beta_{7} \text { DISEXP }+\beta_{8} \text { PDM }+\beta_{9} \text { RIP }+\beta_{10} \text { RPP }+\beta_{11} \text { CEA }+\beta_{12} \text { SEA }+\beta_{13} \text { CA } \\
& +\beta_{14} \text { EXPD }+\beta_{15} \text { ASST }+\beta_{16} \text { LAND }+\beta_{17} \text { TF }+\beta_{18} \text { SHARE }+\beta_{19} \text { RIC } \\
& \left.+\beta_{20} \text { BANK }+\beta_{21} \text { DSTR }+\beta_{22} \text { USTR }+\varepsilon_{i}\right)
\end{aligned}
$$

In ZTPRM, the marginal effect $\left(\frac{\partial y_{i}}{\partial x_{k}}\right)$ of independent variable $k$ with coefficient $\beta_{k}$ can be written as follows:

$$
\frac{\partial y_{i}}{\partial x_{k}}=\beta_{k} e^{\beta_{k} x_{k i}}
$$

The proportion by which the dependent variable changes for a unit change in independent variable $k$ with coefficient $\beta_{k}$ is called Incidence Rate Ratio (IRR). Its equation can be expressed as:

$$
I R R_{x_{k}}=e^{\beta_{k}}
$$

There is a restriction on the ZTPRM: the variance of the model has to be equal to the mean, $\operatorname{Var}(y \mid x)=E(y \mid x)=\gamma$. This assumption can sometimes be violated because the variance in the model $\left(y_{i}\right)$ can be either higher or lower than the mean. To avoid this problem, the standard error has to be adjusted. The zero truncated negative binomial model (ZTNBM) is one of the alternative models after the variance is adjusted. Based on Hilbe [46], after the standard error is adjusted, the variance equation can be written as $\operatorname{Var}(y \mid x)=\gamma_{i}+\alpha \gamma_{i}{ }^{2}$. When the standard error is equal to $0(\alpha=0)$, the model fulfills the assumption (restricted model). Under this condition, the ZTPRM is used. If the standard error is higher than $0(\alpha>0)$, called overdispersion, the ZTNBM is used. When the standard error is lower than $0(\alpha<0)$, this is called underdispersion. To select either a restricted model or unrestricted model, the likelihood statistic test $(\varphi)$ is applied by examining the null hypothesis with an equation, as follows:

$$
\varphi=-2 \log \left(L_{z t n b m}-L_{z t p r m)}\right)
$$

\subsubsection{Categorical Data Estimation: Types of Adopted Ex Post Coping Strategies}

When a disaster occurs, farmers have to adopt ex post coping strategies. These can be categorized based on stress level: low, middle, and high [31,32]. The multinomial logit model (MLM) can be applied in the analysis. When farmer $i$ adopts type $j$ ex post coping strategy, based on Green [45], the equation can be written as:

$$
y_{i j}=\left\{\begin{array}{l}
1=\text { if farmer } i \text { takes ex post coping strategy } j \\
0=\text { otherwise }
\end{array}\right.
$$

Supposing that $x$ represents a variable that influences the decision to adopt a certain type of ex post coping strategy, $\beta$ represents the coefficient of each variable, and $e$ is the base of the natural logarithm, the MLM can be written as:

$$
P\left(y_{i}=j\right)=\frac{e^{\boldsymbol{\beta}_{j}^{\prime} \mathbf{x}_{i}}}{3}, j=1,2,3
$$

The response variable $(j)$ has three possible outcomes: low-stress (1); middle-stress (2); and high-stress (3). In addition, middle-stress (2) is considered as a base case in this study. Therefore, there are two non-redundant sub-models as follows: 


$$
\begin{gathered}
\text { Model } 1=\ln \left(\frac{y_{i}=\text { low }- \text { stress }(1)}{y_{i}=\text { middle }- \text { stress }(2)}\right) \\
=\beta_{0}+\beta_{1} \text { AGE }+\beta_{2} \text { EDU }+\beta_{3} \text { SEX }+\beta_{4} \text { RISK }+\beta_{5} \text { DISC }+\beta_{6} \text { TRUST }+\beta_{7} \text { DISEXP } \\
+\beta_{8} \text { PDM }+\beta_{9} \text { EXPD }+\beta_{10} \text { ASST }+\beta_{11} \text { LAND }+\beta_{12} \text { TF }+\beta_{13} \text { SHARE }+\beta_{14} \text { RIC } \\
+\beta_{15} \text { BANK }+\beta_{16} \text { DSTR }+\beta_{17} \text { USTR }+\varepsilon_{i} \\
\text { Model } 2=\ln \left(\frac{y_{i}=\text { high }- \text { stress }(3)}{y_{i}=\text { middle }- \text { stress }(2)}\right) \\
=\beta_{0}+\beta_{1} \text { AGE }+\beta_{2} \text { EDU }+\beta_{3} \text { SEX }+\beta_{4} \text { RISK }+\beta_{5} \text { DISC }+\beta_{6} \text { TRUST }+\beta_{7} \text { DISEXP } \\
+\beta_{8} \text { PDM }+\beta_{9} \text { EXPD }+\beta_{10} \text { ASST }+\beta_{11} \text { LAND }+\beta_{12} \text { TF }+\beta_{13} \text { SHARE }+\beta_{14} \text { RIC } \\
+\beta_{15} \text { BANK }+\beta_{16} \text { DSTR }+\beta_{17} \text { USTR }+\varepsilon_{i}
\end{gathered}
$$

The marginal effect $\left(\frac{\partial P_{i}}{\partial x_{i}}\right)$ of an independent variable with coefficient $\beta_{k}$ on the probability of adopting ex post coping strategy $j$ can be expressed as:

$$
\frac{\partial P_{i j}}{\partial x_{i}}=P_{i j}\left(\beta_{k}-\bar{\beta}\right)
$$

Theoretically, the decision to adopt ex ante coping strategies, the number of strategies, and the type of ex post coping strategies adopted are often determined by various factors. The independent variables are the following. AGE is the age of the farmer, which can positively and negatively influence adopting coping strategies [37]. EDU is education level. It has been reported to positively determine adopting coping strategies [38,39]. SEX is considered to influence the decision [38]. However, studies differ whether women or men are more likely to adopt the strategies [37,39]. Risk-averse farmers (RISK) are more likely to adopt ex ante coping strategies to minimize the adverse impacts of risk [33,47]. Discount rate (DISC) influences the decision and particularly strategies involving long-term investments such as saving [48]. TRUST among community members is predicted to influence adopting the strategies. Higher trust among communities improves connection (social relation) [49,50]. As a result, risk coping capacity increases as there are many risk coping alternatives available associated with higher connection with other community members, such as borrowing and rotating savings and credit association (ROSCA). Disaster experience (DISEXP) has been found to be a positive determinant of adopting strategies [51,52]. Percentage of damage (PDM) was reported to reduce individuals' resources. Therefore, it decreases the capacity to adopt risk coping strategies [53]. Risk perception variables, which are risk impact perception (RIP) and risk probability perception (RPP), and coping appraisal, namely coping efficacy appraisal (CEA), self-efficacy appraisal (SEA), and cost appraisal (CA), were found to be significant determinants of adopting ex ante coping strategies $[15,17,30]$.

Per capita expenditure (EXPD) positively determines the decision to adopt risk coping strategies [2,34-36]. The influence of land size (LAND) can be positive and negative. Farmers with small land size are reported to adopt ex ante coping strategies, particularly income diversification, whereas farmers who manage middle-sized land are not likely to adopt coping strategies, and allocate all their time to farming $[54,55]$. Access to financial institutions reflected by bank account ownership (BANK) positively influences the decision on risk coping strategies. Borrowing money from financial institutions can be invested in off-farm income-generating activities [56-59]. According to the author's observation, asset (ASST), landholding that is sharecropped (SHARE), rent in cash (RIC), the type of farmland (TF), and the location of farmers, namely downstream (DSTR) and upstream (USTR), were predicted to influence the decision to adopt risk coping strategies. Sharecropping, rent in cash, and privately owned land might have different incomes. Therefore, they have different capacities to adopt risk coping strategies. The type of farmland and location might influence the level of risk. Therefore, it is predicted that these two variables will influence farmers' decisions about risk coping strategies. 
Diagnostic procedures were conducted adequately for reliability analysis as follows: first, variance inflation factors (VIF) were calculated to check for multicollinearity problems among the independent variables. Second, the link test was conducted to determine the right model to use. Third, for the ZTPRM, an adjustment of standard error followed by the likelihood statistic test was undertaken to check whether the model had an overdispersion or underdispersion problem.

\section{Results}

\subsection{Farmers' Characteristics}

As shown in Table 2, most of the interviewed farmers were male (92.2\%). The average age of the farmers was 51.8 years and their education level was 7.3 years. On average, land size managed by farmers was 0.43 ha, of which around three-quarters was irrigated. The largest share of farmers were sharecroppers $(49.4 \%)$.

Table 2. Descriptive summary of farmers' characteristics.

\begin{tabular}{|c|c|c|}
\hline \multirow{2}{*}{ Independent Variable } & \multicolumn{2}{|c|}{ Number of Farmers $=180$} \\
\hline & Mean & SD \\
\hline \multicolumn{3}{|l|}{ Personal characteristics } \\
\hline Age (year) & 51.8 & 8.766 \\
\hline Education (year) & 7.3 & 2.866 \\
\hline Sex (percentage of men) & 92.2 & 0.883 \\
\hline Risk behavior (Rp) & 21,638 & 5280 \\
\hline Discount rate $(\%)$ & 36.9 & 23.73 \\
\hline Trust (Rp) & 8833 & 6233 \\
\hline Disaster experience (times/season) & 1.5 & 0.350 \\
\hline The percentage of damage & 74.6 & 25.78 \\
\hline \multicolumn{3}{|l|}{ Risk perception } \\
\hline Risk impact perception & 0.66 & 0.325 \\
\hline Risk probability perception & 0.83 & 0.341 \\
\hline \multicolumn{3}{|l|}{ Coping appraisal } \\
\hline Coping efficacy perception & 0.79 & 0.314 \\
\hline Self-efficacy perception & 0.68 & 0.278 \\
\hline Cost perception & 0.71 & 0.252 \\
\hline \multicolumn{3}{|l|}{ Economic characteristics } \\
\hline Per capita expenditure (Rp mil/year/person) & 9.7 & 2.127 \\
\hline Asset value (Rp mil) & 91.9 & 98.487 \\
\hline \multicolumn{3}{|l|}{ Farming characteristics } \\
\hline Land size (ha) & 0.43 & 0.295 \\
\hline Type of farmland (\% irrigated land) & 77.2 & 0.421 \\
\hline \multicolumn{3}{|l|}{ Landholding } \\
\hline Sharecropping (\%) & 49.4 & 5.013 \\
\hline Rent-in cash (\%) & 5 & 2.186 \\
\hline \multicolumn{3}{|l|}{ Access to financial institutions } \\
\hline Bank account (\% ownership) & 28.33 & 4.518 \\
\hline \multicolumn{3}{|l|}{ Geographical location } \\
\hline Downstream (\%) & $33 \%$ & 47.27 \\
\hline Midstream (\%) & $33 \%$ & 47.27 \\
\hline
\end{tabular}

Source: Field survey data.

\subsection{Farmers' Experience of Disasters}

There were five types of risks experienced by farmers: drought, flood, pests and diseases, deficit rainfall, and excessive rainfall. Table 3 presents the average number of disasters experienced by farmers during 2012-2017. The most frequent disaster in each crop season was pests and diseases. The least 
frequent disaster was flooding, which occurred in crop Seasons 1 and 2 in downstream and midstream areas. Therefore, the major risk in the area was pests and diseases. This was experienced by all farmers in almost every crop season, and occurred in downstream, midstream, and upstream areas.

Table 3. Average number of disasters.

\begin{tabular}{ccccccccccc}
\hline \multirow{2}{*}{ Type of Disaster } & \multicolumn{4}{c}{ Average Number of Disasters per Season per Farmer } \\
\cline { 2 - 12 } & \multicolumn{3}{c}{ Downstream } & \multicolumn{3}{c}{ Midstream } & \multicolumn{4}{c}{ Upstream } \\
\cline { 2 - 12 } & S1 & S2 & S3 & S1 & S2 & S3 & S1 & S2 & S3 \\
\hline Drought & 0.00 & 0.00 & 0.24 & 0.00 & 0.00 & 0.01 & 0.00 & 0.00 & 0.14 \\
Flood & 0.07 & 0.08 & 0.00 & 0.05 & 0.07 & 0.00 & 0.00 & 0.00 & 0.00 \\
Pests and diseases & 0.30 & 0.32 & 0.29 & 0.32 & 0.35 & 0.27 & 0.33 & 0.34 & 0.31 \\
Rainfall deficit & 0.01 & 0.01 & 0.08 & 0.05 & 0.04 & 0.36 & 0.00 & 0.00 & 0.02 \\
Excessive rainfall & 0.12 & 0.13 & 0.01 & 0.05 & 0.06 & 0.004 & 0.05 & 0.04 & 0.02 \\
\hline
\end{tabular}

Note: S, crop season. S1 and S2 belong to the wet seasons, while S3 to the dry season.

\subsection{Farmers' Risk Coping Strategies}

\subsubsection{Ex Ante Coping Strategies}

There were two types of ex ante coping strategies adopted by farmers: on-farm and off-farm. On-farm coping is a strategy to reduce negative impacts on agricultural production by farming practices, including water management, planting in different plots, and crop diversification. There are three off-farm coping strategies: income diversification, saving, and rotating savings and credit association (ROSCA). According to the survey data, 134 out of 180 farmers (74.4\%) adopted ex ante coping strategies. As shown in Table $4,60 \%$ of farmers used income diversification as a coping strategy, while around one-third used saving $(31.7 \%)$ as a coping strategy. In general, the majority of farmers adopted off-farm strategies compared to on-farm strategies.

The highest number of ex ante coping strategies adopted by a farmer was four (eight farmers). Coping strategies were a mix of on-farm and off-farm. Overall, the number of farmers who adopted more than one type of ex ante coping strategy was higher than farmers who adopted only one type of ex ante coping strategy.

Table 4. Ex ante coping strategies adopted by farmers.

\begin{tabular}{lc}
\hline \multicolumn{1}{c}{ Type } & Number of Farmers (\%) \\
\hline On-farm strategy & $6(3.3 \%)$ \\
Water management & $30(16.7 \%)$ \\
Planting in different plots & $35(19.4 \%)$ \\
Crop diversification & \\
\hline Off-farm strategy & $7(3.8 \%)$ \\
ROSCA & $108(60 \%)$ \\
Income diversification & $57(31.7 \%)$ \\
Saving &
\end{tabular}

Note: Percentages were calculated by dividing the number of farmers adopting an ex ante coping strategy by the total number of farmers (180 farmers). ROSCA, rotating savings and credit association.

\subsubsection{Ex Post Coping Strategies}

All farmers in the study area experienced disasters and adopted ex post coping strategies. There were 10 ex post coping strategies adopted by farmers (Table 5). Overall, most farmers chose middle-stress level types for which the frequency of receiving help from relatives was the highest (122 farmers, 67.7\%). The lowest frequency was four farmers (2.2\%) for taking children out of school. A single farmer might adopt more than one ex post coping strategy. 
At most, four ex ante coping strategies were adopted (three farmers, 1.7\%). The majority of farmers adopted two ex post coping strategies, which accounted for $39.4 \%$ of the total. Farmers who adopted more than one type of ex post coping strategy were more common than farmers who adopted one type of ex post coping strategy.

Table 5. Type of ex post coping strategies adopted by farmers.

\begin{tabular}{lc}
\hline \multicolumn{1}{c}{ Type } & Number of Farmers (\%) \\
\hline Low-stress & $7(3.9 \%)$ \\
Modify consumption pattern & $45(25 \%)$ \\
Increase household budget & \\
\hline Middle-stress & $37(20.6 \%)$ \\
Utilize savings & $34(18.9 \%)$ \\
Borrow from formal and informal sources & $122(67.7 \%)$ \\
Get help from relatives & $22(12.2 \%)$ \\
Migrate to find jobs & \\
\hline High-stress & $13(7.2 \%)$ \\
Sell consumption assets & $25(13.9 \%)$ \\
Sell productive assets & $32(17.8 \%)$ \\
Default on loan(s) & $4(2.2 \%)$ \\
Take children out of school & \\
\hline
\end{tabular}

Note: Percentages were calculated by dividing the number of the farmers taking an ex post coping strategy by the total number of farmers (180 farmers).

\subsection{Farmer Behavior to Risk Coping Strategies}

Identification of farmers' behavior regarding risk coping strategies is essential in order to examine their behavior in spreading risks among the available coping strategies. When farmers adopt ex ante coping strategies, they might adopt a combination of ex ante coping strategies. According to Table 6, when selecting one ex ante coping strategy (59 out of 134 farmers), off-farm strategies were preferred to on-farm strategies, but it is mostly limited to income diversification (47 farmers, $79.7 \%$ ).

Table 6. Combination of ex ante coping strategies adopted by farmers.

\begin{tabular}{|c|c|c|c|c|c|c|c|}
\hline \multirow{2}{*}{$\begin{array}{c}\text { Number of Coping } \\
\text { Strategies }\end{array}$} & \multicolumn{3}{|c|}{ On-Farm Strategy } & \multicolumn{3}{|c|}{ Off-Farm Strategy } & \multirow{2}{*}{$\begin{array}{l}\text { Number of } \\
\text { Farmers (\%) }\end{array}$} \\
\hline & $\begin{array}{c}\text { Water } \\
\text { Management }\end{array}$ & $\begin{array}{c}\text { Planting in } \\
\text { Different Plot }\end{array}$ & $\begin{array}{c}\text { Crop } \\
\text { Diversification }\end{array}$ & ROSCA & $\begin{array}{c}\text { Income } \\
\text { Diversification }\end{array}$ & Saving & \\
\hline 1 & & & $\sqrt{ }$ & & $\sqrt{ }$ & . & $\begin{array}{l}8(13.6 \%) \\
47(79.7 \%\end{array}$ \\
\hline 2 & $\sqrt{ }$ & $\begin{array}{l}\sqrt{ } \\
\sqrt{ } \\
\sqrt{ } \\
\sqrt{ }\end{array}$ & $\begin{array}{l}\sqrt{ } \\
\sqrt{ }\end{array}$ & $\sqrt{ }$ & $\begin{array}{l}\sqrt{ } \\
\sqrt{ } \\
\sqrt{ } \\
\sqrt{ }\end{array}$ & $\begin{array}{l}\sqrt{ } \\
\sqrt{ }\end{array}$ & $\begin{array}{c}2(4.2 \%) \\
8(17 \%) \\
3(6.4 \%) \\
2(4.2 \%) \\
4(8.5 \%) \\
2(4.2 \%) \\
26(55.3 \%)\end{array}$ \\
\hline 3 & $\begin{array}{l}\sqrt{ } \\
\sqrt{ }\end{array}$ & $\begin{array}{l}\sqrt{ } \\
\sqrt{ } \\
\sqrt{ } \\
\sqrt{ }\end{array}$ & $\begin{array}{l}\sqrt{ } \\
\sqrt{ } \\
\sqrt{ } \\
\sqrt{ }\end{array}$ & $\sqrt{ }$ & $\begin{array}{l}\sqrt{ } \\
\sqrt{ } \\
\sqrt{ } \\
\sqrt{ }\end{array}$ & $\begin{array}{l}\sqrt{ } \\
\sqrt{ } \\
\sqrt{ } \\
\sqrt{ } \\
\sqrt{ } \\
\sqrt{ }\end{array}$ & $\begin{array}{c}1(5 \%) \\
2(10 \%) \\
3(15 \%) \\
2(10 \%) \\
6(30 \%) \\
5(25 \%) \\
1(5 \%) \\
\end{array}$ \\
\hline 4 & $\sqrt{ }$ & $\begin{array}{l}\sqrt{ } \\
\sqrt{ } \\
\sqrt{ } \\
\sqrt{ }\end{array}$ & $\begin{array}{l}\sqrt{ } \\
\sqrt{ }\end{array}$ & $\begin{array}{l}\sqrt{ } \\
\sqrt{ } \\
\sqrt{ }\end{array}$ & $\begin{array}{l}\sqrt{ } \\
\sqrt{ }\end{array}$ & $\begin{array}{l}\sqrt{ } \\
\sqrt{ } \\
\sqrt{ } \\
\sqrt{ }\end{array}$ & $\begin{array}{c}4(50 \%) \\
1(12.5 \%) \\
1(12.5 \%) \\
2(25 \%)\end{array}$ \\
\hline
\end{tabular}

In the case of selecting multiple ex ante coping strategies, the most popular selection was a combination of two ex ante coping strategies. Although at first glance the combination was 
varied, the major combination was limited to selecting off-farm strategies rather than combining on-farm and off-farm strategies. Although minor, when selecting three or four ex ante coping strategies, both on-farm and off-farm strategies were combined. However, the water management on-farm strategy and ROSCA off-farm strategy were not highly preferred. In other words, cropping practices, such as planting in different plots and crop diversification, and own capital, such as income diversification and saving, were the major means.

When ex ante coping strategies fail to address risks, farmers rely on ex post coping strategies to cope with loss caused by those risks. Even with ex post coping strategies, farmers can select many ex post coping strategies depending on conditions. As shown in Table 7, in terms of the number of coping strategies, there were 29 combinations of ex post coping strategies. Although two ex post coping strategies were preferred by 71 out of 180 farmers, only one ex post coping strategy (65 farmers out of 180 farmers) was equally high. Adopting three ex post coping strategies ( 31 out of 180 farmers) was less common but represented a significant selection. In terms of combinations from the viewpoint of stress level, ex post coping strategies at the low-stress level were less frequently selected. Even when selecting three ex post coping strategies, middle-stress and high-stress coping strategies were preferred. Selecting only one ex post coping strategy, either "increase in household budget" or "get help from relatives", was comparatively preferred. For selecting two or three ex post coping strategies, although the combinations were diverse, the top three combinations were as follows in terms of mode: "use savings" (middle-stress) and "borrow from formal and informal resources" (middle-stress) (15 farmers, $21.1 \%)$, "get help from relatives" and "default on loans" (14 farmers, 19.7\%), and "get help from relatives", "sell productive assets", and "default on loans" (11 farmers, 26.8\%).

Table 7. Combination of ex post coping strategies adopted by farmers.

\begin{tabular}{|c|c|c|c|c|c|c|c|c|c|c|c|}
\hline \multirow{2}{*}{$\begin{array}{c}\text { Number of } \\
\text { Coping Strategies }\end{array}$} & \multicolumn{2}{|c|}{ Low-Stress } & \multicolumn{4}{|c|}{ Middle-Stress } & \multicolumn{4}{|c|}{ High-Stress } & \multirow{2}{*}{$\begin{array}{l}\text { Number of } \\
\text { Farmers }(\%\end{array}$} \\
\hline & $\mathrm{MCN}$ & IHB & USV & BRW & GHR & MFJ & SCA & SPA & DOL & TCS & \\
\hline 1 & & $\sqrt{ }$ & $\sqrt{ }$ & & $\sqrt{ }$ & & & $\sqrt{ }$ & & & $\begin{array}{c}24(36.9 \%) \\
32(49.2 \%) \\
7(10.8 \%) \\
2(3.1 \%) \\
\end{array}$ \\
\hline 2 & $\sqrt{ }$ & $\begin{array}{l}\sqrt{ } \\
\sqrt{ }\end{array}$ & $\begin{array}{l}\sqrt{ } \\
\sqrt{ }\end{array}$ & $\begin{array}{l}\sqrt{ } \\
\sqrt{ } \\
\sqrt{ }\end{array}$ & $\begin{array}{l}\sqrt{ } \\
\sqrt{ } \\
\sqrt{ } \\
\sqrt{ } \\
\sqrt{ } \\
\sqrt{ }\end{array}$ & $\begin{array}{l}\sqrt{ } \\
\sqrt{ }\end{array}$ & $\begin{array}{l}\sqrt{ } \\
\sqrt{ }\end{array}$ & $\begin{array}{l}\sqrt{ } \\
\sqrt{ }\end{array}$ & . & . & $\begin{array}{c}4(5.6 \%) \\
8(11.3 \%) \\
15(21.1 \%) \\
7(9.9 \%) \\
6(8.4 \%) \\
1(1.4 \%) \\
8(11.3 \%) \\
5(7 \%) \\
14(19.7 \%) \\
2(2.8 \%) \\
1(1.4 \%) \\
\end{array}$ \\
\hline 3 & $\begin{array}{l}\sqrt{ } \\
\sqrt{ }\end{array}$ & $\begin{array}{l}\sqrt{ } \\
\sqrt{ }\end{array}$ & $\begin{array}{l}\sqrt{ } \\
\sqrt{ }\end{array}$ & $\begin{array}{l}\sqrt{ } \\
\sqrt{ } \\
\sqrt{ } \\
\sqrt{ }\end{array}$ & $\begin{array}{l}\sqrt{ } \\
\sqrt{ } \\
\sqrt{ } \\
\sqrt{ } \\
\sqrt{ } \\
\sqrt{ } \\
\sqrt{ } \\
\sqrt{ } \\
\sqrt{ } \\
\sqrt{ } \\
\sqrt{ } \\
\sqrt{ } \\
\sqrt{ }\end{array}$ & $\begin{array}{l}\sqrt{ } \\
\sqrt{ } \\
\sqrt{ } \\
\sqrt{ } \\
\sqrt{ }\end{array}$ & $\begin{array}{l}\sqrt{ } \\
\sqrt{ } \\
\sqrt{ } \\
\sqrt{ } \\
\sqrt{ }\end{array}$ & $\begin{array}{l}\sqrt{ } \\
\\
\sqrt{ } \\
\sqrt{ } \\
\sqrt{ } \\
\sqrt{ }\end{array}$ & $\begin{array}{l}\sqrt{ } \\
\sqrt{ } \\
\sqrt{ } \\
\sqrt{ } \\
\sqrt{ }\end{array}$ & . & $\begin{array}{c}2(4.9 \%) \\
5(12.2 \%) \\
1(2.4 \%) \\
1(2.4 \%) \\
7(17.1 \%) \\
1(2.44 \%) \\
2(4.9 \%) \\
1(2.4 \%) \\
1(2.4 \%) \\
3(7.3 \%) \\
1(2.4 \%) \\
11(26.8 \%) \\
1(2.4 \%) \\
3(7.3 \%) \\
1(2.4 \%) \\
\end{array}$ \\
\hline 4 & & $\begin{array}{l}\sqrt{ } \\
\sqrt{ }\end{array}$ & $\begin{array}{l}\sqrt{ } \\
\sqrt{ }\end{array}$ & $\sqrt{ }$ & $\begin{array}{l}\sqrt{ } \\
\sqrt{ } \\
\sqrt{ }\end{array}$ & $\begin{array}{l}\sqrt{ } \\
\sqrt{ }\end{array}$ & $\begin{array}{l}\sqrt{ } \\
\sqrt{ }\end{array}$ & & & & $\begin{array}{l}1(33.3 \%) \\
1(33.3 \%) \\
1(33.3 \%)\end{array}$ \\
\hline
\end{tabular}

Note: MCP, modification consumption pattern; IHB, increase household budget; USV, utilize savings; BRW, borrow from formal and informal resources; GHR, get help from relative; MFJ, migrate to find jobs; SCA, sell consumption assets; SPA, sell productive assets; DOL, default on loan(s); TCS, take children out from school. 


\subsection{Determinants of Adopting Risk Coping Strategies}

\subsubsection{Determinants of Adopting Ex Ante Coping Strategies}

Table 8 shows estimated coefficients, marginal effects, and odds ratios of parameters from the binomial logit model. According to the Chi-squared test, the joint determinants of adopting ex ante coping strategies are significant at the $1 \%$ level. The result of the link test indicates that the model is precisely specified. Moreover, as the highest value of the variance inflation factor (VIF) is 3.77, there was no multicollinearity in the model. The result shows that risk behavior, disaster experience, coping efficacy, self-efficacy, and per capita expenditure positively and significantly determine the decision on ex ante coping strategies. Meanwhile, discount rate, percentage of damage, cost perception, and land size significantly negatively influence the decision. Farmers in the downstream and midstream area significantly adopt fewer ex ante coping strategies, compared to those in the upstream area.

Table 8. Estimated coefficients, marginal effects, and odds ratios of the binomial logit model.

\begin{tabular}{|c|c|c|c|c|c|c|}
\hline \multirow{2}{*}{ Variable } & \multicolumn{2}{|c|}{ Estimated Coefficient } & \multicolumn{2}{|c|}{ Marginal Effect ${ }^{d}$} & \multirow{2}{*}{ Odds Ratio } & \multirow{2}{*}{ SE } \\
\hline & Coef. & SE & Coef. & SE & & \\
\hline \multicolumn{7}{|c|}{ Dependent variable: 1 if a farmer has adopted ex ante coping strategies, 0 otherwise } \\
\hline Constant & -11.3906 & 5.2333 & & & $0.0001^{-1}$ & $0.0006^{-1}$ \\
\hline \multicolumn{7}{|l|}{ Personal characteristics } \\
\hline $\operatorname{Age}^{2}\left(x_{1}\right)$ & 0.0003 & 0.0006 & $0.0001^{-1}$ & $0.0003^{-1}$ & 1.0003 & 0.0006 \\
\hline Education $\left(\mathrm{x}_{2}\right)$ & 0.4627 & 0.3404 & 0.0261 & 0.0187 & 1.5883 & 0.5407 \\
\hline $\operatorname{Sex}\left(x_{3}\right)$ & 0.4967 & 1.4267 & 0.0279 & 0.0802 & 1.6433 & 2.3445 \\
\hline Risk behavior $\left(\mathrm{x}_{4}\right)$ & $0.0002 * *$ & 0.0001 & $0.0001^{-1 * *}$ & $0.0046^{-4}$ & $1.0002 * *$ & 0.0001 \\
\hline Discount rate $\left(x_{5}\right)$ & $-4.7439 *$ & 2.7574 & -0.2673 * & 0.1496 & $0.0087^{*}$ & 0.0240 \\
\hline Trust $\left(\mathrm{x}_{6}\right)$ & $0.0351^{-4}$ & 0.0001 & $0.0198^{-5}$ & $0.0636^{-4}$ & 1.0000 & 0.0001 \\
\hline Disaster experience $\left(x_{7}\right)$ & $4.3489 *$ & 2.3680 & $0.2451 *$ & 0.1278 & $77.392 *$ & 183.267 \\
\hline Percentage of damage $\left(x_{8}\right)$ & $-0.0601 *$ & 0.0312 & $-0.0034^{*}$ & 0.0017 & $0.9416^{*}$ & 0.0294 \\
\hline \multicolumn{7}{|l|}{ Risk perception } \\
\hline Risk impact $\left(x_{9}\right)$ & 1.4829 & 1.9243 & 0.0836 & 0.1070 & 4.4057 & 8.4779 \\
\hline Risk probability $\left(\mathrm{x}_{10}\right)$ & 0.8031 & 1.4172 & 0.0453 & 0.0795 & 2.2325 & 3.1639 \\
\hline \multicolumn{7}{|l|}{ Coping appraisal perception } \\
\hline Coping efficacy $\left(\mathrm{x}_{11}\right)$ & $2.0901 *$ & 1.2316 & 0.1178 * & 0.0666 & $8.0861 *$ & 9.9586 \\
\hline Self-efficacy $\left(\mathrm{x}_{12}\right)$ & $3.3186 *$ & 1.8304 & 0.1870 * & 0.0989 & $27.6231 *$ & 50.5619 \\
\hline $\operatorname{Cost}\left(\mathrm{x}_{13}\right)$ & $-7.0087^{* * *}$ & 2.2025 & $-0.3949^{* * *}$ & 0.1044 & $0.0009 * * *$ & 0.0019 \\
\hline \multicolumn{7}{|l|}{ Economic characteristics } \\
\hline Per capita expenditure $\left(\mathrm{x}_{14}\right)$ & $1.0496^{* * *}$ & 0.3959 & $0.0592 * * *$ & 0.0208 & $2.8566^{* * *}$ & 1.1308 \\
\hline Asset value $\left(\mathrm{x}_{15}\right)$ & 0.0066 & 0.0117 & 0.0004 & 0.0006 & 1.0066 & 0.0117 \\
\hline \multicolumn{7}{|l|}{ Farming characteristics } \\
\hline 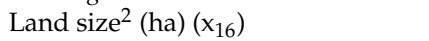 & $-4.1249 *$ & 2.2867 & $-0.2325 *$ & 0.1243 & $0.0162 *$ & 0.0369 \\
\hline Type of farmland $\left(\mathrm{x}_{17}\right)$ & -0.1900 & 1.3056 & -0.0107 & 0.0737 & 0.8269 & 1.0796 \\
\hline \multicolumn{7}{|l|}{ Landholding } \\
\hline Sharecropping $\left(\mathrm{x}_{18}\right)$ & -0.6043 & 0.9038 & -0.0340 & 0.0508 & 0.5464 & 0.4939 \\
\hline Rent-in cash $\left(\mathrm{x}_{19}\right)$ & 0.3559 & 2.0748 & 0.0201 & 0.1168 & 1.4275 & 2.9619 \\
\hline \multicolumn{7}{|l|}{ Access to financial institutions } \\
\hline Bank account $\left(\mathrm{x}_{20}\right)$ & -0.6749 & 2.0881 & -0.0380 & 0.1173 & 0.5092 & 1.0632 \\
\hline \multicolumn{7}{|l|}{ Geographical locations } \\
\hline Down-stream $\left(\mathrm{x}_{21}\right)$ & $-5.3564^{* * *}$ & 2.2804 & $-0.3019^{* *}$ & 0.1199 & $0.0047^{* * *}$ & 0.0108 \\
\hline Midstream $\left(x_{22}\right)$ & $-5.6373^{* *}$ & 1.7401 & $-0.3177^{* * *}$ & 0.0824 & $0.0036^{* * *}$ & 0.0062 \\
\hline Predicted 1s that were actual 1s (\%) & 96.3 & \multicolumn{3}{|c|}{ Log likelihood function } & -32.9992 & \\
\hline Predicted 0 s that were actual 0s (\%) & 91.1 & \multicolumn{3}{|c|}{ Prob $\left(\mathrm{Chi}^{2}>\right.$ value $)$} & 0.0000 & \\
\hline Power of Prediction & 95.0 & \multicolumn{3}{|c|}{ Pseudo $\mathrm{R}^{2}$} & 0.6774 & \\
\hline
\end{tabular}

Notes: ${ }^{* * *}$ significant at $1 \%$ level, ${ }^{* *}$ significant at $5 \%$ level, ${ }^{*}$ significant at $10 \%$ level. ${ }^{\mathrm{d}}$ Marginal effects were computed at the average of marginal effects.

\subsubsection{Determinants of Number of Ex Ante Coping Strategies Adopted}

The number of ex ante coping strategies adopted by a farmer was predicted to be influenced by many factors. The model selected is the ZTPRM. The choice of the model is strengthened by values of 
$\log$ likelihood of the ZTPRM and ZTNBM, which are identical. The result of an overdispersion test showed that the value of $\alpha\left(3.19^{-8}\right)$ in the ZTNBM was equal to 0 . This low value suggests that the variable response was not overdispersed, and that the model needs to follow the restricted model of the ZTPRM instead of the ZTNBM. According to the result of the ZTPRM in Table 9, among independent variables, there were four determinants of the number of ex ante coping strategies adopted: per capita expenditure, land size, disaster experience, and access to financial institutions.

Table 9. Estimated coefficients and marginal effects of the zero truncated Poisson regression model (ZTPRM).

\begin{tabular}{|c|c|c|c|c|c|}
\hline \multirow{2}{*}{ Variable } & \multicolumn{3}{|c|}{ Coefficient Estimates } & \multicolumn{2}{|c|}{ Marginal Effect ${ }^{d}$} \\
\hline & Coefficient & IRR & SE & Coef. & SE \\
\hline \multicolumn{6}{|c|}{ Dependent variable: number of ex ante coping strategies adopted (y) } \\
\hline Constant & -2.9969 & & & & \\
\hline \multicolumn{6}{|l|}{ Personal characteristics } \\
\hline $\operatorname{Age}^{2}\left(x_{1}\right)$ & $-0.0002^{-1}$ & 0.9999 & 0.0002 & $-0.0002^{-1}$ & 0.0002 \\
\hline Education $\left(\mathrm{x}_{2}\right)$ & 0.0002 & 0.0002 & 0.0533 & 0.0002 & 0.0671 \\
\hline $\operatorname{Sex}\left(x_{3}\right)$ & -0.1833 & 0.8325 & 0.3229 & -0.2307 & 0.4884 \\
\hline Risk behavior $\left(\mathrm{x}_{4}\right)$ & $-0.0002^{-1}$ & 0.9999 & $0.0002^{-1}$ & $-0.0001^{-1}$ & $0.0003^{-1}$ \\
\hline Discount rate $\left(x_{5}\right)$ & 0.4458 & 1.5618 & 0.8076 & 0.5612 & 0.6521 \\
\hline Trust $\left(\mathrm{x}_{6}\right)$ & $-0.0001^{-1}$ & 0.9999 & $0.0002^{-1}$ & $-0.0001^{-1}$ & $0.0002^{-1}$ \\
\hline Disaster experience $\left(x_{7}\right)$ & $0.6864 *$ & 1.9865 & 0.7946 & 0.8641 * & 0.5066 \\
\hline Percentage of damage $\left(\mathrm{x}_{8}\right)$ & 0.0023 & 1.0023 & 0.0056 & 0.0029 & 0.0071 \\
\hline \multicolumn{6}{|l|}{ Risk perception } \\
\hline Risk impact $\left(x_{9}\right)$ & 0.7693 & 2.1583 & 1.2420 & 0.9685 & 0.7271 \\
\hline Risk probability $\left(\mathrm{x}_{10}\right)$ & 0.2754 & 1.3170 & 0.7529 & 0.3466 & 0.7202 \\
\hline \multicolumn{6}{|l|}{ Coping appraisal perception } \\
\hline Coping efficacy $\left(\mathrm{x}_{11}\right)$ & -0.0166 & 0.9835 & 0.5130 & -0.0209 & 0.6567 \\
\hline Self-efficacy $\left(\mathrm{x}_{12}\right)$ & 0.5159 & 1.6751 & 0.9070 & 0.6495 & 0.6827 \\
\hline Cost $\left(x_{13}\right)$ & -0.4076 & 0.6653 & 0.3656 & -0.5131 & 0.6927 \\
\hline \multicolumn{6}{|l|}{ Economic characteristics } \\
\hline Per capita expenditure $\left(\mathrm{x}_{14}\right)$ & 0.0695 * & 1.0719 & 0.0439 & 0.0875 * & 0.0519 \\
\hline Asset value $\left(\mathrm{x}_{15}\right)$ & 0.0006 & 1.0006 & 0.0011 & 0.0008 & 0.0014 \\
\hline \multicolumn{6}{|l|}{ Farming characteristics } \\
\hline Land size (ha) $\left(\mathrm{x}_{16}\right)$ & $0.8689 * *$ & 2.3845 & 0.8827 & $1.0939 * *$ & 0.4716 \\
\hline Type of farmland $\left(\mathrm{x}_{17}\right)$ & 0.4210 & 1.5235 & 0.6157 & 0.5300 & 0.5099 \\
\hline \multicolumn{6}{|l|}{ Landholding } \\
\hline Sharecropping $\left(\mathrm{x}_{18}\right)$ & -0.1904 & 0.8266 & 0.2418 & -0.2397 & 0.3686 \\
\hline Rent-in cash $\left(x_{19}\right)$ & -0.2164 & 0.8054 & 0.5271 & -0.2725 & 0.8241 \\
\hline \multicolumn{6}{|l|}{ Access to financial institutions } \\
\hline Bank account $\left(\mathrm{x}_{20}\right)$ & $0.7149^{* *}$ & 2.0439 & 0.7362 & $0.8999 * *$ & 0.4568 \\
\hline \multicolumn{6}{|l|}{ Geographical locations } \\
\hline Down-stream $\left(x_{21}\right)$ & -0.4738 & 0.6226 & 0.2404 & -0.5965 & 0.4877 \\
\hline Midstream $\left(x_{22}\right)$ & -0.3568 & 0.6999 & 0.2445 & -0.4492 & 0.4408 \\
\hline Log likelihood & -122.0770 & & \multirow{2}{*}{\multicolumn{2}{|c|}{ Prob $\left(\mathrm{Chi}^{2}>\right.$ value $)$}} & 0.0000 \\
\hline McFadden Pseudo $\mathrm{R}^{2}$ & 0.2713 & & & & \\
\hline
\end{tabular}

\subsubsection{Determinants of Adopting Ex Post Coping Strategies}

Results of the multinomial logit model (MLM) analysis are presented in Table 10. In the model, the middle-stress coping strategy was set as a base case. The first analysis identified determinants of selecting ex post coping strategies between the low- and middle-stress type. Among the variables, 
percentage of damage, shareropping, and rent-in cash were found to be strongly and positively associated with adopting the low-stress type. Variables that negatively influenced the decision to adopt the low-stress type were education and location in the midstream area. The second analysis identified the determinants of decisions on adopting ex post coping strategy between the middle-stress and the high-stress type. The result showed that percentage of damage, sharecropping, and location in the downstream area were significant positive determinants of the decision to adopt the high-stress type. Disaster experience and asset value were significant negative determinants of the decision.

Table 10. Estimated coefficients and marginal effects of the multinomial logit model.

\begin{tabular}{|c|c|c|c|c|c|}
\hline Variable & $\begin{array}{l}\text { Low-Stress } \\
\text { (Model 1) }\end{array}$ & $\begin{array}{l}\text { High-Stress } \\
\text { (Model 2) }\end{array}$ & $\begin{array}{l}\text { M. Effect of } \\
\text { Low-Stress }\end{array}$ & $\begin{array}{c}\text { M. Effect of } \\
\text { Middle-Stress }\end{array}$ & $\begin{array}{c}\text { M. Effect of } \\
\text { High-Stress }\end{array}$ \\
\hline \multicolumn{6}{|c|}{ Dependent variable: Type of ex post coping strategy adopted, with the middle stress as the base case } \\
\hline Constant & 5.4772 & 8.4523 & & & \\
\hline \multicolumn{6}{|l|}{ Personal characteristics } \\
\hline Age $\left(x_{1}\right)$ & 0.0348 & 0.0026 & 0.0026 & -0.0016 & -0.0010 \\
\hline Education $\left(\mathrm{x}_{2}\right)$ & $-0.6664 *$ & -0.5363 & -0.0334 & 0.0486 & -0.0152 \\
\hline $\operatorname{Sex}\left(x_{3}\right)$ & -2.0622 & -1.0128 & -0.1259 & 0.1267 & -0.0007 \\
\hline Risk behavior $\left(\mathrm{x}_{4}\right)$ & 0.0001 & $0.0005^{-1}$ & $0.0632^{-4}$ & $-0.0630^{-4}$ & $-0.0126^{-6}$ \\
\hline Discount rate $\left(x_{5}\right)$ & -2.2111 & 2.6766 & $-0.2654^{* *}$ & -0.0022 & $0.2676^{*}$ \\
\hline Trust $\left(\mathrm{x}_{6}\right)$ & 0.0001 & 0.0001 & $0.0408^{-4}$ & $-0.0899^{-4}$ & $0.0491^{-4}$ \\
\hline Disaster experience $\left(x_{7}\right)$ & -1.2994 & $-6.2242^{* *}$ & 0.1142 & 0.2848 & $-0.3991^{* *}$ \\
\hline Percentage of damage $\left(\mathrm{x}_{8}\right)$ & $0.0641 * * *$ & $0.0669 * * *$ & 0.0027 & -0.0052 & 0.0026 \\
\hline \multicolumn{6}{|l|}{ Economic characteristics } \\
\hline Per capita expenditure $\left(x_{9}\right)$ & $-0.8548^{* * *}$ & -0.2225 & $-0.0590 * * *$ & $0.0453^{* * *}$ & 0.0138 \\
\hline Asset value $\left(\mathrm{x}_{10}\right)$ & -0.0074 & $-0.0446^{* * *}$ & 0.0009 & $0.0019 *$ & $-0.0029 * *$ \\
\hline \multicolumn{6}{|l|}{ Farming characteristics } \\
\hline Land size (ha) $\left(\mathrm{x}_{11}\right)$ & -3.2919 & -3.558 & -0.1337 & $0.2735 *$ & -0.1398 \\
\hline Type of farmland $\left(\mathrm{x}_{12}\right)$ & 0.2117 & -2.2375 & 0.0941 & 0.0729 & $-0.1669 * *$ \\
\hline \multicolumn{6}{|l|}{ Landholding } \\
\hline Sharecropping $\left(\mathrm{x}_{13}\right)$ & $4.5743^{* * *}$ & $2.0257^{* *}$ & $0.2869^{* * *}$ & $-0.2729^{* * *}$ & -0.0139 \\
\hline Rent-in cash $\left(x_{14}\right)$ & $3.1849 *$ & -0.3417 & $0.2605^{* *}$ & -0.1258 & -0.1348 \\
\hline \multicolumn{6}{|l|}{ Access to financial institutions } \\
\hline Bank account $\left(\mathrm{x}_{15}\right)$ & -0.2832 & -15.1517 & 0.5030 & 0.5683 & -1.0713 \\
\hline \multicolumn{6}{|l|}{ Geographic locations } \\
\hline Down-stream $\left(\mathrm{x}_{16}\right)$ & 0.7632 & $4.2844 *$ & -0.0889 & $-0.1904 *$ & $0.2792 *$ \\
\hline Midstream $\left(\mathrm{x}_{17}\right)$ & $-2.1524^{* *}$ & 1.3892 & $-0.2162^{* * *}$ & 0.0425 & 0.1737 * \\
\hline Log likelihood & -70.8098 & Prob $>$ chi $^{2}$ & 0.0000 & & \\
\hline Pseudo $\mathrm{R}^{2}$ & 0.6002 & & & & \\
\hline
\end{tabular}

Note: ${ }^{* * *}$ significant at $1 \%$ level, ${ }^{* *}$ significant at $5 \%$ level, ${ }^{*}$ significant at $10 \%$ level. ${ }^{\mathrm{d}} \mathrm{M}$. Effect, marginal effect, computed at the average of marginal effect.

\section{Discussion}

This study investigated the determinants of decisions to adopt ex ante coping strategies and the number of strategies adopted. The study identified the determinants of decisions on the type of ex post coping strategies adopted.

The result of the logit model showed that risk-averse farmers significantly adopt ex ante coping strategies to anticipate the negative impacts of future risks. Risk-averse households tend to diversify income, even though the total income might be lower [33]. This result confirms the finding of previous studies that risk-averse farmers tend to use crop diversification as one of the ex ante coping strategies to reduce failures in production $[31,32,47,60]$. Farmers who have a higher discount rate significantly do not adopt ex ante coping strategies. This finding is similar to that of Reardon and Vosti [48], who stated that farmers may have a high discount rate and may sacrifice long-term objectives (reducing the adverse impact of risks). A higher discount rate means that farmers value current resources higher than those of the future. This means that farmers prefer present benefits from their current resources over those in the future. This condition reduces farmers' investments allocated for ex ante coping strategies such as saving, from which the benefit will be enjoyed by farmers in the future. 
Disaster experience significantly determines the decision to adopt ex ante coping strategies. Influence of disaster experience on adopting ex ante coping strategies was consistent with findings in Bangladesh and in the U.S. [51,52]. Disaster experience delivers knowledge of the adverse impacts of disasters on farmer wealth. As a result, their motivation to adopt ex ante coping strategies increases. Percentage of damage has a negative impact on adopting ex ante coping strategies. This is because a higher percentage of damage means that farmers' income is lower; therefore, farmers have a lower capacity to invest in ex ante coping strategies. As reported by Warner et al. [53], the percentage of damage influences the capacity of individuals to cope with risks.

In terms of prediction, each coping appraisal perception variable-coping efficacy, self-efficacy, and cost-are important determinants of implementing ex ante coping strategies. Farmers who have higher coping efficacy and self-efficacy perceptions significantly adopt ex ante coping strategies to minimize the impact of risks. Conversely, farmers who have higher cost perception significantly do not implement ex ante coping strategies, in line with previous findings $[15,17,18,30]$. In contrast with the prediction, risk perception variables (risk probability and risk impact) were not significant for adopting ex ante coping strategies. According to the survey data, most farmers reported that the probability of disaster occurrence was high, particularly with respect to pests and diseases. Therefore, there was almost no difference in terms of risk probability between farmers who took on and those who did not take on ex ante coping strategies. This condition might have occurred because the objective of ex ante coping strategies is to minimize the adverse impact of various risks (five risks in the present study) $[12,61,62]$. The insignificant risk perception of adopting ex ante coping strategies is similar with previous findings [63-66], which analyzed the effect of risk perception on adopting protective responses to minimize the impact of floods.

Regarding economic characteristics, per capita expenditure is a determinant of adopting ex ante coping strategies. Farmers with higher per capita expenditure significantly adopt ex ante coping strategies, because farmers with high per capita income have more capacity to do so [2,34-36].

Farming characteristics are expected to be essential to the decision to adopt ex ante coping strategies. Land size had a negative impact on the decision. This finding is similar to those of previous reports [54,55]. According to the survey, because of small land size, farmers had enough time to undertake off-farm income-generating activities as sources of ex ante coping. Farmers who managed middle-sized land tended to concentrate on farming as a main income source and allocated all their time to farming. However, because of small incomes, they could not save part of their incomes as an ex ante coping strategy. In contrast, farmers who managed larger land sizes could adopt ex ante coping strategies, such as saving, because, with larger land sizes, they could earn higher incomes. Therefore, farmers who had larger land sizes significantly adopted ex ante coping strategies. This condition fitted in the model when the land size variable was converted into a squared variable; it increased the prediction power.

Regarding geographical location, the result indicates that farmers in the downstream and midstream areas adopt fewer ex ante coping strategies compared to those in the upstream area. This is because farmers in the downstream and midstream areas have a higher percentage of damage, compared to those in the upstream area. Moreover, in the upstream area, there are many options for cropping due to favorable agro-climatic conditions, resulting in their crop diversification every season as an ex ante coping strategy.

Different numbers of ex ante coping strategies are chosen by farmers. To minimize the total income risk, farmers adopt different strategies [67]. The number of ex ante coping strategies adopted reflects the intensity of the desire to reduce the negative impacts of disasters. An increase in the number of strategies strengthens the capacity of farmers to reduce the impact of disasters, but this reduces valuable resources, not only in terms of money, but also time. 
The result of the ZTPRM showed that per capita expenditure, land size, disaster experience, and access to financial institutions are determinants of decisions on the number of ex ante coping strategies adopted. Even though access to financial institutions is not a significant determinant in adopting ex ante coping strategies, further investigation of farmers who choose ex ante coping strategies showed that this variable positively determines the number of ex ante coping strategies adopted. Access to financial institutions might increase the capacity of farmers to implement ex ante coping strategies. For instance, farmers use a financial institution to save some parts of their income and to borrow money to be invested in off-farm income-generating activities [56-59]. It is likely that economic affordability (deriving from income, large land size, and access to financial institutions) enables farmers to invest in several coping strategies.

Farmers rely on an ex post coping strategy to cope with the risks when ex ante coping strategies fail to address the risks. The stress level of the strategy adopted influences farmers' adaptive capacity to anticipate future risks. The result of the MLM to identify determinants of decisions to take on ex post coping strategies between the low-stress and the middle-stress type shows that, among personal characteristics, education and percentage of damage are significant determinants of selecting the lowand middle-stress types. Farmers with a higher education level significantly adopt middle-stress coping strategies rather than low-stress coping strategies. This might be because farmers with a higher education level have a better ability to process information [68]. For instance, migrating to find jobs should be easier for farmers with a higher education level because it requires the processing of complicated information to find a suitable job. Madison [69] stated that farmers with a higher education level are more likely to employ coping strategies to minimize the adverse impacts of risks. Farmers who have experienced a higher percentage of damage significantly adopt low-stress coping strategies rather than the middle-stress strategies. This is likely because the higher percentage of damage resulted in lower incomes. Accordingly, instead of high investments, such as migrating to find jobs, which enables compensation for large-scale damage, farmers increase their household budget to fulfill their basic needs by minimizing unnecessary spending and modifying consumption patterns as ex post coping strategies.

Among economic characteristics, per capita expenditure was a significant factor for selecting the low- and middle-stress strategies. Farmers with higher per capita expenditure significantly selected the middle-stress coping strategy. For farming characteristics, sharecropping and rent in cash farmers were determinants of taking on ex post coping strategies. Farmers who practiced sharecropping and rent in cash farmers significantly selected the lower-stress coping strategy compared to that of owner farmers. This is because they produce lower incomes due to paying a share of products and rent to land owners. According to the survey data, farmers who practiced sharecropping and rent in cash had lower per capita incomes by $46.6 \%$ and $10.9 \%$, respectively, compared to those of owner farmers.

From the geographical aspect, farmers in the midstream area significantly adopted the middle-stress type rather than the lower-stress type. According to the survey data, farmers in the midstream area had higher per capita incomes by $24.5 \%$, and almost three times higher saving values, but were $13.3 \%$ less likely to take credit compared to those in the upstream area.

The result of the MLM in identifying the determinants of decisions regarding ex post coping strategies between the middle-stress and the high-stress types showed that disaster experience and percentage of damage significantly influence the selection of ex post coping categories. Farmers who experienced several disasters choose middle-stress rather than high-stress type. Conversely, farmers who experienced a higher percentage of damage adopt the high-stress rather than the middle-stress type. Sharecroppers significantly adopt the high-stress rather than the middle-stress type. Asset value is a significant determinant of selecting between the high-stress and the middle-stress type. Farmers with a higher asset value tend to select the middle-stress type because they could easily pay the cost of coping strategies. Farmers in the downstream area significantly adopt the high-stress type compared to farmers in the upstream area. 
The result of the analysis of the type of ex post coping strategies adopted showed that the more prosperous farmers (higher per capita expenditure and asset value) select the middle-stress type and, after that, the low-stress and the high-stress categories. This means that as long as farmers can use their savings, borrow from formal or informal sources, migrate to find jobs, and obtain help from relatives, they avoid reducing consumption and expenditure, selling productive and consumption assets, defaulting on loans, and taking children out from school as ex post coping strategies.

Implications for governmental policy, in particular, should focus on increasing farmers' risk coping capacities, including farmers' participation in agricultural insurance schemes. According to the results of this study, access to financial institutions reflected by bank account ownership positively influenced farmers' decisions regarding the number of adopted ex ante coping strategies. This highlights the opportunity for policymakers, such as the government, to formulate a policy to increase farmers' adaptive capacity, including by purchasing agricultural insurance. Increasing access to financial institutions is one of the policies that can be implemented by the government. This provides opportunities for farmers to increase incomes. For instance, farmers might borrow money to be invested in off-farm income-generating activities or to pay for crop diversification. When farmers' incomes rises, farmers can increase their risk coping capacity by adopting more than one ex ante coping strategy. In the long term, the policy might increase the participation rate in agricultural insurance because agricultural insurance will be more affordable to farmers when they have a higher income. This study reveals that a psychological factor-coping appraisal perception-is a significant determinant for adopting ex ante coping strategies. Therefore, the government should also improve farmer awareness of ex ante coping strategies. Increasing awareness of ex ante coping strategies will influence coping appraisal perception. As a result, farmers' willingness to implement ex ante coping strategies or adaptive capacity would be expected to increase.

There is a limitation to the present study. Some variables have a low significance level $(10 \%$ significance level). This might be because risks faced by farmers in the survey area included several risks. Therefore, ex ante coping strategies adopted by farmers were used to minimize the negative impacts of several future risks. It is important to identify farmers' behavior in terms of ex ante coping strategies on a certain type of risk. As such, the significance level of the variables could be measured precisely.

\section{Conclusions}

Most farmers (74.4\%) adopted ex ante coping strategies. These farmers had certain characteristics: higher risk aversion, higher per capita expenditure, and greater experience of disasters, but lower discount rate and percentage of damage, and location in downstream and midstream areas. The present study clarifies that coping appraisal perception determines the decision to adopt coping strategies. This finding confirms that socio-psychological aspects are essential factors in choosing coping strategies.

The majority of farmers implement more than one type of coping strategy. They combine strategies either within the same type (on-farm or off-farm) or across on-farm and off-farm strategies. The main selection is a combination of two off-farm strategies (income diversification and saving). Four significant determinants regarding the number of ex ante coping strategies adopted are as follows: per capita expenditure, land size, disaster experience, and access to financial institutions.

The present study shows that all farmers adopt ex post coping strategies. The most common coping strategy is the middle-stress coping strategy. When adopting more than one coping strategy, farmers prefer combinations within the same stress level (low, middle, or high) or across different types. Prosperous farmers tend to select the middle-stress followed by the low-stress type. 
The government should increase farmers' access to financial institutions to increase their adaptive capacity. Such a policy would provide opportunities for farmers to increase income. As income increases, the capacity of farmers to adopt ex ante strategies increases. The government should also improve farmers' awareness of ex ante strategies. In the long-term, policies might increase agricultural insurance participation rates.

The present study is one of the studies on farmers' risk coping behavior that applies the PMT framework. Therefore, this is an important study of the socio-cognitive model of adaptation and adaptive capacity, and an example of the studies in behavioral research in agriculture associated with coping risks in a developing country. Moreover, this study presents a case study. Therefore, the result might not reflect farmers' behavior in the country as a whole. Nevertheless, the framework will be useful for future research investigating farmers' risk coping behavior in other areas in Indonesia as well as in developing countries.

Funding: This research received no external funding.

Acknowledgments: The author is grateful to the National Development Planning Agency (Bappenas) of the Republic of Indonesia for offering a scholarship for doctoral study at the Graduate School of International Development, Nagoya University.

Conflicts of Interest: The author declares no conflict of interest.

\section{References}

1. Hardaker, J.B.; Lien, G.; Anderson, J.R.; Huirne, R.B.M. Coping with Risk in Agriculture, Applied Decision Analysis, 3rd ed.; CABI: Boston, MA, USA, 2015.

2. Morduch, J. Income smoothing and consumption smoothing. J. Econ. Perspect. 1995, 9, 103-114. [CrossRef]

3. Cooper, P.; Dimes, J.; Rao, K.; Shiferaw, B.; Twomlow, S. Copying Better with Current Climatic Variability in the Rain-Fed Farming Systems of the Sub-Saharan Africa: A Dress Rehearsal for Adapting to Future Climate Change; International Crop Research Institute for the Semi-Arid Tropics: Harare, Zimbabwe, 2006; pp. 5-7.

4. Sawada, Y. The impact of natural and manmade disasters on household welfare. Agric. Econ. 2007, 37, 59-73. [CrossRef]

5. Chuku, C.A.; Okoye, C. Increasing resilience and reducing vulnerability in Sub-Saharan African agriculture: Strategies for risk coping and management. Afr. J. Agric. Res. 2009, 4, 1524-1535.

6. World Bank. World Development Report 2000/2001: Attacking Poverty; World Bank: Washington, DC, USA, 2001.

7. National Disaster Management Authority (BNPB). Natural Hazards in Indonesia; BNPB: Jakarta, Indonesia, 2017.

8. The Ministry of Agriculture (MoA). Statistics of Climate, Crop Pest and Diseases and Climate Change Impact 2012-2014; The Ministry of Agriculture: Jakarta, Indonesia, 2017.

9. Intergovernmental Panel on Climate Change (IPCC). Climate Change 2001: Impacts, Adaptation, and Vulnerability. Contribution of Working Group II to the Third Assessment Report of the IPCC I; Cambridge University Press: Cambridge, UK, 2001; pp. 6-12.

10. Asuransi Jasa Indonesia (Jasindo). Agricultural Insurance Customer Data; Jasindo: Jakarta, Indonesia, 2017; Unpublished.

11. Barnett, J.; Graham, S.; Mortreux, C.; Fincher, R.; Waters, E.; Hurlimann, E. A local coastal adaptation pathway. Nat. Clim. Chang. 2014, 4, 1103-1108. [CrossRef]

12. Osbahr, H.; Twyman, C.; Adger, W.N.; Thomas, D.S.G. Effective livelihood adaptation to climate change disturbance: Scale dimensions of practice in Mozambique. Geoforum 2008, 39, 1951-1964. [CrossRef]

13. Huitema, D.; Adger, W.N.; Berkhout, F.; Massey, E.; Mazmanian, D.; Munaretto, S.; Plummer, R.; Termeer, C.C.J.A.M. The governance of adaptation: Choices, reasons, and effects. Introduction to the special feature. Ecol. Soc. 2016, 21, 37. [CrossRef]

14. Pelling, M. Adaptation to Climate Change: From Resilience to Transformation; Routledge: London, UK, 2011.

15. Grothmann, R.; Patt, A. Adaptive capacity and human cognition: The process of individual adaptation to climate change. Glob. Environ. Chang. 2005, 15, 199-213. [CrossRef] 
16. Rogers, R.W. A protection motivation theory of fear appeals and attitude change. J. Consum. Psychol. 1975, 91, 93-114.

17. Grothmann, T.; Reusswig, F. People at risk of flooding: Why some residents take precautionary action while others do not. Nat. Hazards 2006, 38, 101-120. [CrossRef]

18. Bubeck, P.; Botzen, W.J.W.; Laudan, J.; Aerts, J.C.J.H.; Thieken, A.H. Insights into flood-coping appraisals of protection motivation theory: Empirical evidence from Germany and France. Risk Anal. 2018, 38, 1239-1257. [CrossRef]

19. Martin, I.M.; Bender, H.; Raish, C. What motivates individuals to protect themselves from risks: The case of wildland fires. Risk Anal. 2007, 27, 887-900. [CrossRef] [PubMed]

20. Mankad, H.; Greenhill, M.; Tucker, D.; Tapsuwan, S. Motivational indicators of protective behaviour in response to urban water shortage threat. J. Hydrol. 2013, 491, 100-107. [CrossRef]

21. Barness, H.; Carrico, A.R.; Thabrew, L. A socio-psychological model for analyzing climate change adaptation: A case study of Sri Lankan paddy farmers. Glob. Environ. Chang. 2015, 31, 85-97. [CrossRef]

22. Eriksen, S.H.; Brown, K.; Kelly, P.M. The dynamics of vulnerability: Locating coping strategies in Kenya and Tanzania. Geogr. J. 2005, 171, 287-305. [CrossRef]

23. Kelly, P.M.; Adger, W.N. Theory and practice in assessing vulnerability to climate change and facilitating adaptation. Clim. Chang. 2000, 47, 325-352. [CrossRef]

24. Yohe, G.; Tol, R.S.J. Indicators for social and economic coping capacity-moving toward a working definition of adaptive capacity. Glob. Environ. Chang. 2002, 12, 25-40. [CrossRef]

25. Berman, R.; Quinn, C.; Paavola, J. The role of institutions in the transformation of coping capacity to sustainable adaptive capacity. Environ. Dev. 2012, 2, 86-100. [CrossRef]

26. Engle, N.L. Adaptive capacity and its assessment. Glob. Environ. Chang. 2017, 2, 647-656. [CrossRef]

27. Rogers, R.W.; Prentice-Dunn, S. Protection motivation theory. In Handbook of Health Behavior Research; Plenum: New York, NY, USA, 1997; Volume 1, pp. 113-132.

28. Paxson, C.H. Using weather variability to estimate the response of savings to transitory income in Thailand. Am. Econ. Rev. 1992, 82, 15-33. [CrossRef]

29. Milne, S.; Sheeran, P.; Orbell, S. Prediction and intervention in health-related behavior: A meta-analytic review of protection motivation theory. J. Appl. Soc. Psychol. 2000, 30, 106-143. [CrossRef]

30. Gebrehiwot, T.; van der Ven, A. Farmers prone to drought risk: Why Some farmers undertake farm-level risk-reduction measures while others not? Environ. Manag. 2015, 55, 588-602. [CrossRef] [PubMed]

31. Montgomery, R. Disciplining or protecting the poor? Avoiding the social costs of peer pressure in micro-credit schemes. J. Int. Dev. 1996, 8, 289-305. [CrossRef]

32. Cohen, M.; Sebstad, J. Reducing vulnerability: The demand for microinsurance. J. Int. Dev. 2005, 17, 397-474. [CrossRef]

33. Ellis, F. The determinants of rural livelihood diversification in developing countries. J. Agric. Econ. 2000, 51, 289-302. [CrossRef]

34. Reardon, T.; Delgado, C.; Matlon, P. Determinants and effects of income diversification amongst farm households in Burkina Faso. J. Dev. Stud. 1992, 28, 264-292. [CrossRef]

35. Rosenzweig, M.R.; Wolpin, K.I. Credit market constraints, consumption smoothing, and the accumulation of durable production assets in low-income countries: Investments in bullocks in India. J. Political Econ. 1993, 101, 223-244. [CrossRef]

36. Dorward, A. Modelling embedded risk in peasant agriculture: Methodological insights from northern Malawi. Agric. Econ. 1999, 21, 191-203. [CrossRef]

37. Kochar, A. Smoothing consumption by smoothing income: Hours-of-work responses to idiosyncratic agricultural shocks in rural India. Rev. Econ. Stat. 1999, 81, 50-61. [CrossRef]

38. Bryan, E.; Deressa, T.T.; Gbetibouo, G.A.; Ringler, C. Adaptation to climate change in Ethiopia and South Africa: Options and constraints. Environ. Sci. Policy 2009, 12, 413-426. [CrossRef]

39. Dillon, A.; Mueller, V.; Salau, S. Migratory responses to agricultural risk in northern Nigeria. Am. J. Agric. Econ. 2011, 93, 1048-1061. [CrossRef]

40. Central Bureau of Statistics (CBS). Garut District in Figures; CBS: Garut, Indonesia, 2016.

41. The Ministry of Agriculture (MoA). Census of Agriculture 2013; The Ministry of Agriculture of the Republik of Indonesia: Jakarta, Indonesia, 2013. 
42. Schechter, L. Traditional trust measurement and the risk confound: An experiment in rural Paraguay. J. Econ. Behav. Organ. 2007, 62, 272-292. [CrossRef]

43. Kirby, K.N.; Godoy, R.; Reyes-Garcia, V.; Byron, E.; Apaza, L.; Leonard, W.; Perez, E.; Vadez, V.; Wilkie, D. Correlates of delay-discount rates: Evidence from Tsimane'Amerindians of the Bolivian rain forest. J. Econ. Psychol. 2002, 23, 291-316. [CrossRef]

44. Wooldridge, J.M. Introductory Econometric: A Modern Approach, 5th ed.; South-Western Cengage Learning: Mason, OH, USA, 2013.

45. Green, W.H. Econometric Analysis, 5th ed.; Prentice Hall: Prentince, WI, USA, 2003.

46. Hilbe, J.M. Negative Binomial Regression, 2nd ed.; Cambridge University Press: New York, NY, USA, 2011.

47. Di Falco, S.; Chavas, J.P. On crop biodiversity, risk exposure, and food security in the highlands of Ethiopia. Am. J. Agric. Econ. 2009, 91, 599-611. [CrossRef]

48. Reardon, T.; Vosti, S.A. Link between rural poverty and the environment in developing countries: Asset categories and investment poverty. World Dev. 1995, 23, 1495-1506. [CrossRef]

49. Adger, W.N. Social capital, collective action, and adaptation to climate change. Econ. Geogr. 2003, 79, 387-404. [CrossRef]

50. Stone, W. Measuring Social Capital: Towards a Theoretically Informed Measurement Framework for Researching Social Capital in Family and Community Life. In Towards a Theoretically Informed Measurement Framework for Researching Social Capital in Family and Community Life; Australian Institute of Family Studies: Melbourne, Australia, 2001; pp. 1-46.

51. Freedy, J.R.; Shaw, D.L.; Jarrell, M.P.; Masters, C.R. Towards an understanding of the psychological impact of natural disasters: An application of the conservation resources stress model. J. Trauma. Stress 1992, 5, 441-454. [CrossRef]

52. Alam, E.; Collins, A.E. Cyclone disaster vulnerability and response experiences in coastal Bangladesh. Disasters 2010, 34, 931-954. [CrossRef]

53. Warner, K.; Geest, K.V.D.; Kreft, S.; Huq, S.; Harmeling, S.; Kusters, K.; Sherbinin, A.D. Evidence from the Frontlines of Climate Change: Loss and Damage to Communities Despite Coping and Adaptation; United Nations University Institute for Environment and Human Security (UNU-EHS): Bonn, Germany, 2012; pp. 1-86.

54. Shand, R.T. Agricultural development, non-farm employment and rural income distribution: A case study in Kelantan Malaysia. In Off-Farm Employment in the Development of Rural Asia; Australian National University: Canberra, Australia, 1986.

55. Reardon, T.; Taylor, J.E.; Stamoulis, K.; Lanjouw, P.; Balisacan, A. Effects of non-farm employment. J. Agric. Econ. 2000, 51, 266-288. [CrossRef]

56. Jacob, Y. Successful Rural Finance Institutions. Financ. Dev. 1994, 31, 32-35.

57. Dercon, S. Wealth, risk and activity choice: Cattle in Western Tanzania. J. Dev. Econ. 1998, 55, 1-42. [CrossRef]

58. Barret, C.B.; Reardon, T.; Webb, P. Nonfarm income diversification and household livelihood strategies in rural Africa: Concepts, dynamics, and policy implications. Food Policy 2001, 26, 315-331. [CrossRef]

59. McPeak, J.G.; Barret, C.B. Differential risk exposure and stochastic poverty traps among East African pastoralists. Am. J. Agric. Econ. 2001, 83, 674-679. [CrossRef]

60. Bezabih, M.; Sarr, M. Risk preferences and environmental uncertainty: Implications for crop diversification decisions in Ethiopia. Environ. Resour. Econ. 2012, 53, 483-505. [CrossRef]

61. Burnham, M.; Ma, Z. Multi-scalar pathways to smallholder adaptation. World Dev. 2018, 108, $249-262$. [CrossRef]

62. Feola, G.; Lerner, A.M.; Jain, M.; Montefrio, M.J.F.; Nicholas, K.A. Researching farmer behaviour in climate change adaptation and sustainable agriculture: Lessons learned from five case studies. J. Rural Stud. 2015, 39, 74-84. [CrossRef]

63. Kreibich, H.; Thieken, A.H.; Petrow, T.; Muller, M.; Merz, B. Flood loss reduction of private households due to building precautionary measures-lessons learned from the Elbe flood in August 2002. Nat. Hazards Earth Syst. Sci. 2005, 5, 117-126. [CrossRef]

64. Miceli, R.; Sotgiu, I.; Settanni, M. Disaster preparedness and perception of flood risk: A study in an alpine valley in Italy. J. Environ. Psychol. 2008, 28, 164-173. [CrossRef]

65. Takao, K. Factors determining disaster preparedness in residents: Differences in terms of homeownership and age. Kaw. J. Med. Welfare 2003, 9, 21-29. 
66. Thieken, A.H.; Kreibich, H.; Muller, M.; Merz, B. Coping with floods: Preparedness, response and recovery of flood-affected residents in Germany in 2002. Hydrol. Sci. J. 2007, 52, 1016-1037. [CrossRef]

67. Walker, T.S.; Ryan, J.G. Village and Household Economies in India's Semi-Arid Tropics; John Hopkins University Press: Baltimore, MD, USA, 1990.

68. Norris, P.E.; Batie, S.S. Virginia farmers' soil conservation decisions: An application of the tobit analysis. South. J. Agric. Econ. 1987, 19, 79-90. [CrossRef]

69. Maddison, D. The Perception of and Adaptation to Climate Change in Africa; The World Bank: Washington, DC, USA, 2007; pp. 1-51.

(C) 2019 by the author. Licensee MDPI, Basel, Switzerland. This article is an open access article distributed under the terms and conditions of the Creative Commons Attribution (CC BY) license (http://creativecommons.org/licenses/by/4.0/). 